\title{
Cancer Center Planning Grant
}

National Cancer Institute

\section{Source}

National Cancer Institute. Cancer Center Planning Grant. NCI Thesaurus. Code C39340.

The Cancer Center Planning Grant (P20) is an NCl-provided grant available to research organizations interested in developing an $\mathrm{NCl}$-designated Cancer Center. P20 Grant can be awarded for a maximum of 3 years of support. The applicant must identify the cancer center concept to be promoted within its institution, research objectives for the center, and ensure research goals are translated into improved patient care, cancer prevention and control, education programs, and community information services. At the end of the P20 grant cycle, the organization should be prepared to submit a CCSG application. 